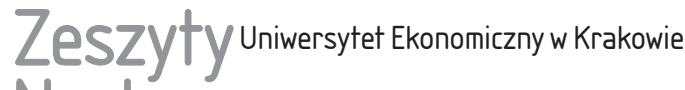 Naukowe
}

$10(934)$

ISSN 1898-6447

Zesz. Nauk. UEK, 2014; 10 (934): 35-50 DOI: 10.15678/ZNUEK.2014.0934.1003

Stawomir Juszczyk

Rafat Balina

Olaf Kowalski

Katedra Ekonomiki i Organizacji Przedsiębiorstw

Szkoła Główna Gospodarstwa Wiejskiego w Warszawie

\section{Determinanty efektywności banków spółdzielczych w Polsce w latach 2005-2012}

\section{Streszczenie}

W badaniach autorzy podjęli próbę określenia kluczowych czynników wpływających na efektywność polskich banków spółdzielczych w latach 2005-2012. Badaniami objęto próbę losowo wybranych 124 banków spółdzielczych, które nieprzerwanie prowadziły swoją działalność w okresie badawczym. W trakcie badań określono, z wykorzystaniem modeli danych panelowych, czynniki warunkujące poziom zysku netto, rentowność funduszy własnych, rentowność aktywów ogółem oraz marżę finansową w badanych bankach. Pod uwagę wzięto 20 zmiennych określających sytuację ekonomiczno-finansową banków spółdzielczych, z których 12 okazało się istotnymi. Ważne jest to, że 3 zmienne, tj. kredyty dla sektora rolniczego, depozyty przedsiębiorstw, spółek prywatnych i spółdzielni oraz depozyty przedsiębiorców indywidualnych, były kluczowe niezależnie od przyjętej miary efektywności.

Słowa kluczowe: efektywność, modele, banki spółdzielcze, rentowność funduszy własnych.

\section{Wprowadzenie}

Banki spółdzielcze w Polsce stanowią część sektora bankowego. W okresie transformacji systemowej podlegały głębokim reformom instytucjonalnym oraz 
konkurencji na rynku usług finansowych [Balina, Pochopień i Idasz-Balina 2013]. Koncepcja restrukturyzacji banków spółdzielczych i spółdzielczego sektora bankowego zmieniała się, co pociągnęło za sobą nakłady finansowe zarówno ze środków samych banków, jak i systemu finansowego państwa. Dominowała idea zwiększania bezpieczeństwa banków spółdzielczych, dlatego stymulowano procesy konsolidacyjne, z którymi wiązało się oczekiwanie wyższej efektywności wynikającej m.in. z racjonalizacji struktury organizacyjnej i efektów skali [Jaworski 1997].

Funkcjonowanie banków spółdzielczych ma złożone podstawy teoretyczne, a ich identyfikacja wymaga rozważenia co najmniej dwóch zagadnień. $\mathrm{Z}$ jednej strony są to spółdzielnie, specyficzne podmioty z punktu widzenia teorii firmy, z drugiej zaś to banki, czyli instytucje kredytowe [Szambelańczyk 2006]. Oznacza to, że banki spółdzielcze są podmiotami o złożonej charakterystyce, a pełnione przez nie funkcje mają istotny wpływ na ich działalność. Złożoność ta nie pozostaje bez wpływu na efektywność banków spółdzielczych, które w Europie wyraźnie wyróżniają się na tle banków komercyjnych m.in. tym, że w czasie ostatniego kryzysu nie wymagały dokapitalizowania ze strony któregokolwiek państwa członkowskiego Unii Europejskiej [Balina, Kowalski i Różyński 2014]. Jednocześnie Europejski Bank Centralny, obserwując różnorodność modeli biznesowych, wskazuje, że model bankowości spółdzielczej oferuje m.in. korzyści w postaci zwiększonej stabilności finansowej.

Banki spółdzielcze mają szczególne znaczenie dla społeczności, gdyż z jednej strony są pośrednikami między uczestnikami rynku, którzy posiadają nadwyżki finansowe, a tymi, którzy potrzebują tych środków, aby realizować swoje inwestycje [Mikołajczak 1998]. Z drugiej strony są instytucjami, których celem jest zaspokajanie potrzeb spółdzielców, a nie tylko dążenie do osiągania zysków. Dlatego też ważnym warunkiem, który powinien spełniać bank spółdzielczy, jest efektywność działania.

Pojęcie efektywności może być różnie definiowane - jako uzyskanie możliwie najwyższych efektów przy danych nakładach lub uzyskanie oczekiwanych efektów przy możliwie najniższych nakładach [Ušàk 2006].

Zagadnienie efektywności banków spółdzielczych w Polsce w ujęciu mikroekonomicznym jest $w$ dalszym ciągu niewystarczająco rozpoznane zarówno w nauce, jak i w praktyce, m.in. ze względu na utrudniony dostęp do odpowiednich danych. W literaturze przedmiotu dominują ujęcia wynikające ze stosowania klasycznych miar statystyki opisowej (średnie, dynamika, przedziały klasowe) i podstawowych wskaźników finansowych ( $R O A, R O E, C / I$, jakość należności itp.) [Farrel 2008]. Problematyka efektywności banków jest tymczasem bardzo złożona i obejmuje obszary, które są ściśle związane m.in. z działalnością depozytowo-kredytową [Stiroh 2004]. W Polsce banki spółdzielcze, które formą organizacyjną 
odpowiadają zarówno instytucjom spółdzielczym, jak i kredytowym, są podmiotami, w których odpowiednie funkcje i tym samym procesy obejmują specyficzną sferę - w pewnym sensie wykraczającą poza typową dla banków komercyjnych [Juszczyk i in. 2014]. Implikuje to konieczność szczególnego rozważenia zagadnienia efektywności działania banków spółdzielczych w kontekście ich specyfiki. Dlatego też za cel główny opracowania przyjęto rozpoznanie czynników warunkujących efektywność polskich banków spółdzielczych.

\section{Metodyka badań}

Okres badawczy obejmuje lata 2005-2012, tj. począwszy od pierwszego pełnego roku członkostwa Polski w Unii Europejskiej. Do badań wybrano wszystkie banki spółdzielcze zrzeszone w Spółdzielczej Grupie Bankowej (SGB) według stanu na 1 stycznia 2005 r. Ze względu na zmianę liczby banków spółdzielczych należących do Spółdzielczej Grupy Bankowej w okresie badawczym ostatecznie badaniami objęto 124 banki spółdzielcze, które w latach 2005-2012 nieprzerwanie prowadziły swoją działalność oraz nie podlegały istotnym zmianom organizacyjnym. Banki objęte badaniami stanowiły 82,67\% należących do Spółdzielczej Grupy Bankowej. Materiał źródłowy stanowiły sprawozdania finansowe opublikowane w Monitorze Spółdzielczym B, dane statystyczne Komisji Nadzoru Finansowego oraz dane statystyczne Spółdzielczej Grupy Bankowej.

Efektywność badanych banków spółdzielczych rozpatrywano, biorąc pod uwagę: wskaźnik rentowności aktywów ogółem $(R O A)$, wskaźnik rentowności kapitału własnego $(R O E)$, poziom generowanego wyniku finansowego netto $(Z N)$ oraz poziom marży finansowej $(M F)$.

W celu określenia czynników wpływających na efektywność banków spółdzielczych w okresie badawczym w pierwszej kolejności wybrano potencjalne zmienne objaśniające efektywność banków spółdzielczych. Wśród wytypowanych zmiennych znalazły się: $X_{1}$ - suma bilansowa ogółem (tys. zł), $X_{2}$ - fundusze własne banku (tys. zł), $X_{3}$ - liczba zatrudnionych (osoby), $X_{4}$ - współczynnik wypłacalności (\%), $X_{5}$ - kredyty ogółem (tys. zł), $X_{6}$ - kredyty dla przedsiębiorstw i spółek prywatnych oraz spółdzielni (tys. zł), $X_{7}$ - kredyty dla przedsiębiorców indywidualnych (tys. zł), $X_{8}$ - kredyty dla osób prywatnych (tys. zł), $X_{9}$ - kredyty sektora rolniczego (tys. zł), $X_{10}$ - kredyty dla instytucji niekomercyjnych (tys. zł), $X_{11}$ - depozyty ogółem (tys. zł), $X_{12}$ - depozyty przedsiębiorstw i spółek prywatnych oraz spółdzielni (tys. zł), $X_{13}$ - depozyty przedsiębiorców indywidualnych (tys. zł), $X_{14}$ - depozyty osób prywatnych (tys. zł), $X_{15}$ - depozyty sektora rolniczego (tys. zł), $X_{16}$ - depozyty instytucji niekomercyjnych (tys. zł), $X_{17}$-środki zgromadzone na rachunkach bieżących przez klientów banku (tys. zł). 
W związku z tym w badaniach wykorzystano zbilansowane dane panelowe pochodzące ze 124 banków spółdzielczych z lat 2005-2012 dotyczące 17 zmiennych objaśniających.

Czynniki określające efektywność banków spółdzielczych wybrano z wykorzystaniem modelu panelowego [Pindyck i Rubinfeld 1998, Maddala 2006]. Estymacja modelu panelowego może zostać wykonana za pomocą klasycznej metody najmniejszych kwadratów, w przypadku gdy spełniony był warunek zgodności estymatora klasycznej metody najmniejszych kwadratów dla błędu całkowitego $E\left(v_{i t}\right)=0, \operatorname{Cov}\left(V_{i t}, x_{i t}\right)=0$ oraz dla czystego błędu losowego $E\left(\varepsilon_{i t}\right)=0$, $\operatorname{Cov}\left(\varepsilon_{i t}, x_{i t}\right)=0$ dla $i=1, \ldots, N, t=1, \ldots, T$, a także nie występowała korelacja między efektem indywidualnym $\mu_{i}$ i zmienną objaśniającą $x_{i t}$ [Borkowski, Dudek i Szczęsny 2003]. Aby stwierdzić, czy dany model panelowy można było estymować za pomocą klasycznej metody najmniejszych kwadratów, należało zweryfikować hipotezę o istnieniu efektu indywidualnego [Dziechciarz 2003]. Posłużono się przy tym testem Breuscha-Pagana o następujących hipotezach:

$$
\begin{aligned}
& H_{0}: \sigma_{u}^{2}=0, \\
& H_{0}: \sigma_{u}^{2} \neq 0 .
\end{aligned}
$$

Niech zatem $S_{1}=\sum_{t=1}^{T}\left(\sum_{t=1}^{T} u_{i t}\right)^{2}$ oraz $S_{2}=\sum_{i=1}^{N} \sum_{t=1}^{T} u_{i t}^{2}$, gdzie $u_{i t}$ są resztami z oszacowanego modelu klasyczną metodą najmniejszych kwadratów. Jeżeli dodatkowo składnik losowy ma rozkład normalny oraz dysponujemy dużą liczbą obserwacji, to wówczas statystyka testu Breuscha-Pagana jest następująca: $\lambda=\frac{N T}{2(T-1)}\left(\frac{S_{1}}{S_{2}}-1\right)^{2}$ i ma rozkład $X^{2}$ z 1 stopniem swobody. Brak podstaw do odrzucenia hipotezy zerowej oznacza nieistotną zmianę wariancji przy wprowadzeniu efektów indywidualnych, więc dodatnie tych efektów jest zbyteczne, natomiast przyjęcie hipotezy alternatywnej wskazuje zasadność wprowadzenie efektów indywidualnych. W przypadku ich występowania należało rozpatrzyć dwa przypadki: efekty ustalone oraz efekty losowe [Draper i Smith 1998]. W sytuacji gdy w modelu występują efekty ustalone, wówczas model panelowy ma postać:

$$
y_{i t}=x_{i t} \beta+u_{i}+\varepsilon_{i t},
$$

gdzie $u_{i}$ to efekt indywidualny, natomiast $\varepsilon_{i t}$ to czysty błąd losowy. Ustalone efekty indywidualne eliminowano przez uśrednienie modelu względem czasu. Powyższe równanie przyjmowało wówczas postać:

$$
\frac{1}{T} \sum_{t=1}^{T} y_{i t}=\frac{1}{T} \sum_{t=1}^{T} x_{i t} \beta+\frac{1}{T} \sum_{t=1}^{T} u_{i}+\frac{1}{T} \sum_{t=1}^{T} \varepsilon_{i t},
$$

co równoważnie można zapisać jako:

$$
\bar{y}_{i}=\bar{x}_{i} \beta+u_{i}+\bar{\varepsilon}_{i} .
$$


Odejmując stronami powyższe dwa równania, otrzymywano:

$$
y_{i t}-\bar{y}_{i}=\left(x_{i t}-\bar{x}_{i}\right) \beta+\left(\varepsilon_{i t}-\bar{\varepsilon}_{i}\right) .
$$

Warto podkreślić, że stały efekt indywidualny $u_{i}$ został wyeliminowany, a jeśli przyjęto $\tilde{y}_{i t}=y_{i t}-\bar{y}_{i}, \tilde{x}_{i t}=x_{i t}-\bar{x}_{i}$ oraz $\tilde{\varepsilon}_{i t}=\varepsilon_{i t}-\bar{\varepsilon}_{i}$, otrzymywano model $\tilde{y}_{i t}=\tilde{x}_{i t} \beta+\tilde{\varepsilon}_{i t}$, który po oszacowaniu za pomocą klasycznej metody najmniejszych kwadratów dawał estymator parametrów strukturalnych następującej postaci:

$$
\hat{\beta}_{F E}=\left(\tilde{X}^{T} \bar{X}\right)^{-1} \tilde{X}^{T} \tilde{y},
$$

gdzie:

$\tilde{X}$ - macierz przekształconych zmiennych objaśniających $\tilde{x}_{i t}$,

$\tilde{y}$ - wektor przekształconych zmiennych objaśnianych.

Należy podkreślić, że pomijano w tym wypadku sytuację ścisłej egzogeniczności oraz występowania zmiennych, których wartości są stałe w czasie dla wszystkich jednostek w panelu. Następnie wykonywano test na zróżnicowanie wyrazu wolnego, który miał na celu wskazanie uzasadnienia zastosowania estymacji modelu panelowego z ustalonymi efektami.

Drugim rodzajem efektów indywidualnych są efekty losowe, jeśli przyjąć, że efekty indywidualne $u_{i}$ są zmienną losową. Dodatkowo wiadomo, że zazwyczaj nie są one skorelowane z czystym błędem $\operatorname{losowym} \operatorname{Cov}\left(u_{i}, \varepsilon_{i t}\right)=0$, dla $t=1, \ldots, T$. Łączny błąd losowy, składający się z efektu indywidualnego oraz czystego błędu losowego, $v_{i t}=u_{i}+\varepsilon_{i t}$, charakteryzuje się zatem korelacją w tym samym obiekcie, zakłada się natomiast brak korelacji dla różnych obiektów. Taka sytuacja wymagała więc zastosowania uogólnionej metody najmniejszych kwadratów, przy czym uogólniony estymator najmniejszych kwadratów parametrów strukturalnych $\hat{\beta}_{R E}$ ma postać:

$$
\hat{\beta}_{R E}=\left(X^{T} \Omega X\right)^{-1} X^{T} \Omega^{-1} y,
$$

gdzie:

$X$ - macierz zmiennych objaśniających,

$y$ - wektor zmiennych objaśniających,

$\Omega$ - odwracalna macierz wariancji i kowariancji łącznego błędu losowego:

$$
\Omega=\operatorname{Var}(v)=\left[\begin{array}{ccc}
\operatorname{Var}\left(v_{1}\right) & \cdots & 0 \\
\vdots & \ddots & \vdots \\
0 & \cdots & \operatorname{Var}\left(v_{N}\right)
\end{array}\right] .
$$

Ważnym aspektem jest właściwy wybór między efektami ustalonymi a efektami losowymi. Pomocny przy tym wyborze był test Hausmana, badający występowanie korelacji między zmiennymi objaśniającymi a efektami losowymi. Test ten 
pozwolił na sprawdzenie, czy estymatory efektów ustalonych i losowych są zbieżne do tego samego punktu. Założone hipotezy mają postać: $H_{0}: \operatorname{Cov}\left(u_{i} x_{i t}\right)=0$, przeciwko $H_{1}: \operatorname{Cov}\left(u_{i} x_{i t}\right) \neq 0$. Statystyka służąca weryfikacji określona jest wzorem: $q=\hat{\beta}_{F E}-\hat{\beta}_{R E}$ i jest zbieżna do rozkładu $X^{2}$ o $k$ stopniach swobody, gdzie $k$ jest liczbą zmiennych objaśniających. Brak podstaw do odrzucenia hipotezy zerowej wskazuje na zgodność obu estymatorów - dla efektów ustalonych i efektów losowych, przy czym estymator efektów losowych jest bardziej efektywny. Odrzucenie hipotezy zerowej sugerował wybór efektów ustalonych.

\section{Czynniki warunkujące poziom zysku netto w badanych bankach spółdzielczych}

W pierwszej kolejności dokonano określenia czynników warunkujących zysk netto w badanych bankach spółdzielczych. Model oszacowano z wykorzystaniem modelu panelowego skonstruowanego dla ośmioletniego okresu badawczego. Do oszacowania modelu panelowego użyto uogólnionej metody najmniejszych kwadratów, gdyż test Breuscha-Panga wskazał na istnienie efektów indywidualnych, test Hausmana natomiast wskazał na efekty losowe. Ostateczną postać funkcji regresji przedstawiono w tabeli 1. Przeprowadzone badania wykazały, że na zysk netto w okresie badawczym wpływało 10 zmiennych. Kluczowe dla objaśnienia zysku netto okazały się:

- fundusze własne ogółem,

- liczba zatrudnionych,

- kredyty dla przedsiębiorstw i spółek prywatnych oraz spółdzielni,

- kredyty dla przedsiębiorstw indywidualnych,

- kredyty dla sektora rolniczego,

- kredyty dla instytucji niekomercyjnych,

- depozyty od przedsiębiorstw i spółek prywatnych oraz spółdzielni,

- depozyty od przedsiębiorców indywidualnych,

- depozyty osób prywatnych,

- środki zgromadzone na rachunkach bieżących przez klientów banku.

Przeprowadzona analiza statystyczna wykazała ponadto, że oszacowany model charakteryzował się wysokim współczynnikiem determinacji, co oznaczało, że skonstruowany model wyjaśniał ponad $87,6 \%$ zmienności zysku netto badanych banków spółdzielczych w okresie badawczym. Ponadto test $F$ wskazał na nieprzypadkowość zmiennych objaśniających w objaśnianiu zmienności zysku netto. Uwzględniając wyniki testu zmiennych, należy stwierdzić, że było one istotne przy poziomie istotności wynoszącym 0,05 , co potwierdza wartość parametru $p$ 
dla poszczególnych zmiennych. Co ciekawe, spośród 10 zmiennych, które znalazły się w modelu, 4 okazały się destymulantami tj.:

- liczba zatrudnionych,

- kredyty dla sektora rolniczego,

- depozyty przedsiębiorstw i spółek prywatnych oraz spółdzielni,

- środki zgromadzone na rachunkach bieżących przez klientów banku.

Tabela 1. Model panelowy zysku netto (tys. zł) dla badanych banków spółdzielczych

\begin{tabular}{|c|c|c|}
\hline Zmienne & Współczynnik & Wartość $p$ \\
\hline Const & 66,016 & 0,13242 \\
\hline$X_{2}$ - fundusze własne banku (tys. zł) & 0,08162 & 0,00001 \\
\hline$X_{3}-$ liczba zatrudnionych (osoby) & $-3,85975$ & 0,00001 \\
\hline $\begin{array}{l}X_{6}-\text { kredyty dla przedsiębiorstw i spółek } \\
\text { prywatnych oraz spółdzielni (tys. zł) }\end{array}$ & 0,00927479 & 0,00001 \\
\hline $\begin{array}{l}X_{7}-\text { kredyty dla przedsiębiorców indywidu- } \\
\text { alnych (tys. zł) }\end{array}$ & 0,00151364 & 0,00001 \\
\hline$X_{9}-$ kredyty sektora rolniczego (tys. zł) & $-0,00808834$ & 0,00001 \\
\hline $\begin{array}{l}X_{10}-\text { kredyty dla instytucji niekomercyj- } \\
\text { nych (tys. zł) }\end{array}$ & 0,00123907 & 0,00005 \\
\hline $\begin{array}{l}X_{12}-\text { depozyty przedsiębiorstw i spółek } \\
\text { prywatnych oraz spółdzielni (tys. zł) }\end{array}$ & $-0,0208121$ & 0,00001 \\
\hline $\begin{array}{l}X_{13}-\text { depozyty przedsiębiorców indywidu- } \\
\text { alnych (tys. zł) }\end{array}$ & 0,00484394 & 0,00001 \\
\hline$X_{14}-$ depozyty osób prywatnych (tys. zł) & 0,00918628 & 0,00001 \\
\hline $\begin{array}{l}X_{17}-\text { środki zgromadzone na rachunkach } \\
\text { bieżących przez klientów banku (tys. zł) }\end{array}$ & $-0,00328501$ & 0,02267 \\
\hline$R^{2}$ & \multicolumn{2}{|c|}{0,876404} \\
\hline$F(10 ; 981 ; 0,05)$ & \multicolumn{2}{|c|}{695,6145} \\
\hline Statystyka testu Breuscha-Pagana & \multicolumn{2}{|c|}{33,1666} \\
\hline Statystyka testu Hausmana & \multicolumn{2}{|c|}{20,128} \\
\hline
\end{tabular}

Źródło: badania własne.

Może to wskazywać, że w okresie badawczym w badanej grupie banków spółdzielczych przyrost zatrudnienia o jedną osobę powodował spadek zysku netto, przy innych czynnikach niezmienionych, o blisko 3,86 tys. zł$^{1}$. Przyrost o 1 tys. zł kredytów dla sektora rolniczego powodował spadek zysku netto o ponad 8 zł.

${ }^{1} \mathrm{~W}$ dalszej części artykułu interpretacja współczynników regresji oszacowanych modeli panelowych informuje o przyroście/spadku przeciętnym. Dodatkowo interpretacja zawiera założenie o niezmienności pozostałych czynników. 
Mógł to być wynik tego, że banki spółdzielcze w dużej mierze udzielały podmiotom rolniczym kredytów na preferencyjnych warunkach, co mimo rekompensat od instytucji rządowych nie przysparzało bankowi w tym czasie oczekiwanych korzyści finansowych. W przypadku wzrostu depozytów przedsiębiorstw i spółek prywatnych oraz spółdzielni o 1 tys. zł następował spadek zysku netto o ponad 20 zł. Oznacza to, że oferta skierowana do tej grupy klientów badanych banków spółdzielczych była zbyt droga dla banków.

Wzrost o 1 tys. zł zmiennej określonej jako środki zgromadzone na rachunku bieżącym przez klientów banków powodował spadek zysku netto o ponad 3 zł. Pozostałe sześć zmiennych charakteryzowało się dodatnim współczynnikiem regresji, co oznacza, że ich wzrost o 1 tys. zł powodował przyrost zysku netto o ponad 81 zł dla funduszy własnych ogółem, o ponad 9 zł w przypadku kredytów dla przedsiębiorstw i spółek prywatnych oraz spółdzielni, o 1,5 zł w przypadku kredytów dla przedsiębiorców indywidualnych, o ponad 1,2 zł w przypadku kredytów dla instytucji niekomercyjnych, o blisko 5 zł w przypadku depozytów przedsiębiorców indywidualnych i o ponad 9 zł w przypadku depozytów osób prywatnych.

\section{Czynniki kształtujące poziom ROE w badanych bankach spółdzielczych}

W dalszym etapie badań określono czynniki warunkujące poziom rentowności funduszy własnych w badanych bankach spółdzielczych. Do oszacowania funkcji regresji wykorzystano uogólnioną metodę najmniejszych kwadratów, co było następstwem występowania w modelu losowego efektu indywidualnego. W ostatecznym modelu znalazły się następujące zmienne:

- liczba zatrudnionych,

- współczynnik wypłacalności,

- kredyty sektora rolniczego,

- kredyty dla instytucji niekomercyjnych,

- depozyty przedsiębiorstw i spółek prywatnych oraz spółdzielni,

- depozyty przedsiębiorców indywidualnych.

Biorąc pod uwagę wartość $p$ oszacowaną dla poszczególnych zmiennych i przyjęty poziom istotności wynoszący 0,05 , stwierdzono, że zmienne te były istotne dla objaśnienia zmienności $R O E$. Spośród kluczowych zmiennych wpływających na poziom rentowności funduszy własnych badanych banków spółdzielczych 4 zmienne były destymulantami. Wzrost zatrudnienia o 1 powodował spadek $R O E$ o ponad 0,3 punktu procentowego, wzrost współczynnika wypłacalności o 1 punkt procentowy przyczyniał się do spadku $R O E$ o ponad 0,14 punktu procentowego. 
Tabela 2. Model panelowy ROE (\%) dla badanych banków spółdzielczych

\begin{tabular}{|l|c|c|}
\hline \multicolumn{1}{|c|}{ Zmienna } & Współczynnik & Wartość $p$ \\
\hline Const & 17,8603 & 0,00001 \\
\hline$X_{3}-$ liczba zatrudnionych (osoby) & $-0,0302294$ & 0,00096 \\
\hline$X_{4}-$ współczynnik wypłacalnó́ci (\%) & $-0,144035$ & 0,00031 \\
\hline$X_{9}-$ kredyty sektora rolniczego (tys. zł) & 0,0000309379 & 0,00990 \\
\hline $\begin{array}{l}X_{10}-\text { kredyty dla instytucji niekomercyj- } \\
\text { nych (tys. zł) }\end{array}$ & 0,000822869 & 0,00860 \\
\hline $\begin{array}{l}X_{12}-\text { depozyty przedsiębiorstw i spółek } \\
\text { prywatnych oraz spółdzielni (tys. zł) }\end{array}$ & $-0,000114922$ & 0,01139 \\
\hline $\begin{array}{l}X_{13}-\text { depozyty przedsiębiorców indywidu- } \\
\text { alnych (tys. zł) }\end{array}$ & $-0,000167429$ & 0,00001 \\
\hline$R^{2}$ & & 0,857717 \\
\hline$F(7,984)$ & 8,610286 \\
\hline Statystyka testu Breuscha-Pagana & \multicolumn{2}{|c|}{99,8707} \\
\hline Statystyka testu Hausmana & 9,79875 \\
\hline
\end{tabular}

Źródło: badania własne.

Dodatkowo przyrost depozytów przedsiębiorstw i spółek prywatnych oraz spółdzielni i depozytów przedsiębiorców indywidualnych przyczyniał się do spadku $R O E$ odpowiednio o ponad 0,11 zł dla $X_{12}$ oraz o ponad 0,16 zł dla zmiennej $X_{13}$. Pozostałe dwie zmienne określające poziom kredytów dla sektora rolniczego oraz dla instytucji niekomercyjnych były stymulantami, czyli ich przyrost o 1 tys. zł powodował odpowiednio przyrost $R O E$ o pond 0,03 i 0,8 punktu procentowego.

\section{Czynniki kształtujące poziom ROA w badanych bankach spółdzielczych}

Kolejnym badanym zagadnieniem było określenie kluczowych czynników warunkujących stopę zwrotu z aktywów ogółem badanych banków spółdzielczych. Przeprowadzona analiza statystyczna wykazała, że najlepszą metodą estymacji modelu panelowego ROA w okresie badawczym była uogólniona metoda najmniejszych kwadratów - wynikało to z testu Breuscha-Pagana i testu Hausmana, które wskazały na występowanie losowego efektu indywidualnego. Ponadto zestawienie poziomu istotności na poziomie $0,05 \mathrm{z}$ wartością $p$ oszacowaną dla poszczególnych zmiennych wskazało na ich statystyczną istotność. Przeprowadzono również ocenę stopnia dopasowania oszacowanego modelu do danych i na jej podstawie stwierdzono, że oszacowana funkcja regresji rentowności aktywów ogółem badanych banków w latach 2005-2012 wyjaśniała ponad 77\% zmienności zmiennej 
objaśnianej. Ponadto test Fishera-Snedecora wykazał, że zmienne w modelu były nieprzypadkowe. W oszacowanym modelu panelowym rentowności aktywów własnych badanych banków spółdzielczych znalazło się 9 zmiennych, wśród których 3 były stymulantami:

- fundusz własne banku,

- kredyty dla osób prywatnych,

- kredyty sektora rolniczego.

Pozostałe 6 zmiennych charakteryzowało się ujemnym współczynnikiem regresji, $\mathrm{tj}$.:

- liczba zatrudnionych,

- współczynnik wypłacalności,

- depozyty przedsiębiorstw i spółek prywatnych oraz spółdzielni,

- depozyty przedsiębiorców indywidualnych,

- depozyty osób prywatnych,

- środki zgromadzone na rachunku bieżącym przez klientów banku.

Na podstawie wyników badań przedstawionych w tabeli 3 można było stwierdzić, że ceteris paribus przyrost funduszy własnych o 1 tys. zł powodował wzrost $R O A$ o ponad 0,02 punktu procentowego. W przypadku przyrostu o 1 tys. zł kredytów dla osób prywatnych i kredytów dla sektora rolniczego stwierdzono zwiększenie się ROA odpowiednio o ponad 0,006 i 0,005 punktu procentowego. Oznacza to, że w przypadku zarządzania bankiem spółdzielczym oraz chęci zwiększania $R O A$ ważne jest zwracanie szczególnej uwagi na poziom funduszy własnych oraz skupianie swojej działalności kredytowej na osobach prywatnych oraz podmiotach sektora rolniczego, które przynoszą stosunkowo wysokie korzyści bankom.

W oszacowanym modelu rentowności aktywów ogółem badanych banków spółdzielczych w latach 2005-2012 znalazły się także inne zmienne, wśród których należy zwrócić uwagę na liczbę zatrudnionych, która wpływała ujemnie na wartość uzyskiwanego ROA. Jak wynika z oszacowanego modelu, wzrost zatrudnienia o jedną osobę powodował spadek $R O A$ o ponad 0,002 punktu procentowego, co może świadczyć o tym, że zatrudnienie w bankach spółdzielczych jest już na wysokim poziomie i zwiększenie zatrudnienia nie przekłada się na wzrost wydajności pracy. W związku z tym banki spółdzielcze, podejmując decyzje o zatrudnieniu nowych pracowników, powinny bardzo dokładnie przeanalizować, czy istnieje taka potrzeba.

Następną zmienną, która znalazła się w modelu panelowym, jest współczynnik wypłacalności, który charakteryzował się ujemnym wpływem na rentowność funduszy własnych badanych banków. Oznacza to, że wzrost współczynnika wypłacalności o 1 punkt procentowy powodował spadek rentowności aktywów ogółem o blisko 0,0035 punktu procentowego. Może to być wynik tego, że w większości 
przypadków banki spółdzielcze dążą do obniżania współczynnika wypłacalności przy jednoczesnym zachowaniu jego bezpiecznego poziomu, gdyż na ogół pozwala to na uzyskiwanie większej efektywności.

Tabela 3. Model panelowy ROA (\%) dla badanych banków spółdzielczych

\begin{tabular}{|c|c|c|}
\hline Zmienna & Współczynnik & Wartość $p$ \\
\hline Const & 0,997118 & 0,00001 \\
\hline$X_{2}$ - fundusze własne banku (tys. zł) & 0,000021199 & 0,00088 \\
\hline$X_{3}-$ liczba zatrudnionych (osoby) & $-0,0023745$ & 0,00461 \\
\hline$X_{4}$ - współczynnik wypłacalności (\%) & $-0,00344878$ & 0,00001 \\
\hline$X_{8}-$ kredyty dla osób prywatnych (tys. zł) & 0,00000432238 & 0,03122 \\
\hline$X_{9}$ - kredyty sektora rolniczego (tys. zł) & 0,00000614385 & 0,00001 \\
\hline $\begin{array}{l}X_{12}-\text { depozyty przedsiębiorstw i spółek } \\
\text { prywatnych oraz spółdzielni (tys. zł) }\end{array}$ & $-0,00000505451$ & 0,00402 \\
\hline $\begin{array}{l}X_{13}-\text { depozyty przedsiębiorców indywidu- } \\
\text { alnych (tys. zł) }\end{array}$ & $-0,0000112848$ & 0,02559 \\
\hline$X_{14}-$ depozyty osób prywatnych (tys. zł) & $-0,00000205455$ & 0,04114 \\
\hline $\begin{array}{l}X_{17} \text { - środki zgromadzone na rachunkach } \\
\text { bieżących przez klientów banku (tys. zł) }\end{array}$ & $-0,00000601799$ & 0,00001 \\
\hline$R^{2}$ & \multicolumn{2}{|c|}{0,773618} \\
\hline$F(9,982)$ & \multicolumn{2}{|c|}{122,92354} \\
\hline Statystyka testu Breuscha-Pagana & \multicolumn{2}{|c|}{128,483} \\
\hline Statystyka testu Hausmana & \multicolumn{2}{|c|}{20,1884} \\
\hline
\end{tabular}

Źródło: badania własne.

Istotne jest to, że przyrost depozytów pochodzących od przedsiębiorstw i spółek prywatnych, przedsiębiorców indywidualnych, osób prywatnych oraz środków zgromadzonych na rachunkach bieżących klientów banków powodował spadek rentowności aktywów ogółem.

\section{Czynniki kształtujące poziom marży finansowej w bankach spółdzielczych}

W ostatnim etapie badań ustalono kluczowe czynniki wpływające na poziom marży finansowej uzyskiwanej w okresie badawczym przez banki spółdzielcze. Do ich wyznaczenia wykorzystano, tak jak w poprzednich przypadkach, uogólnioną metodę najmniejszych kwadratów, która pozwoliła na szacowanie modelu panelowego przy występowaniu indywidualnych efektów ustalonych. Uwzględ- 
nienie wartości $p$ i poziomu istotności wynoszącego 0,05 wskazało na istotność zmiennych w oszacowanym modelu panelowym. W tabeli 4 przedstawiono wyniki estymacji modelu panelowego marży finansowej dla badanych banków.

Z badań wynika, że oszacowany model charakteryzował się wysokim stopniem dopasowania do danych, gdyż współczynnik determinacji modelu wyniósł ponad $85 \%$. W modelu znalazło się 10 zmiennych:

- fundusze własne banku,

- liczba zatrudnionych,

- współczynnik wypłacalności,

- trzy zmienne określające poziom udzielonych kredytów,

- trzy zmienne określające wysokość zgromadzonych depozytów,

- jedna zmienna odnosząca się do środków zgromadzonych na rachunkach bieżących przez klientów banku.

Tabela 4. Model panelowy marży finansowej (\%) dla badanych banków spółdzielczych

\begin{tabular}{|c|c|c|}
\hline Zmienna & Współczynnik & Wartość $p$ \\
\hline Const & 4,11658 & 0,00001 \\
\hline$X_{2}$ - fundusze własne banku (tys. zł) & 0,000168294 & 0,00001 \\
\hline$X_{3}-$ liczba zatrudnionych (osoby) & $-0,0319325$ & 0,00001 \\
\hline$X_{4}$ - współczynnik wypłacalności (\%) & $-0,0435926$ & 0,01829 \\
\hline $\begin{array}{l}X_{6}-\text { kredyty dla przedsiębiorstw i spółek } \\
\text { prywatnych oraz spółdzielni (tys. zł) }\end{array}$ & 0,0000194568 & 0,00033 \\
\hline$X_{8}-$ kredyty dla osób prywatnych (tys. zł) & 0,0000281245 & 0,00076 \\
\hline$X_{9}-$ kredyty sektora rolniczego (tys. zł) & 0,0000241649 & 0,00001 \\
\hline $\begin{array}{l}X_{12}-\text { depozyty przedsiębiorstw i spółek } \\
\text { prywatnych oraz spółdzielni (tys. zł) }\end{array}$ & $-0,0000189706$ & 0,01855 \\
\hline $\begin{array}{l}X_{13}-\text { depozyty przedsiębiorców indywidu- } \\
\text { alnych (tys. zł) }\end{array}$ & 0,000118014 & 0,00001 \\
\hline$X_{14}-$ depozyty osób prywatnych (tys. zł) & $-0,000016971$ & 0,00020 \\
\hline $\begin{array}{l}X_{17} \text { - środki zgromadzone na rachunkach } \\
\text { bieżących przez klientów banku (tys. zł) }\end{array}$ & $-0,0000507018$ & 0,00001 \\
\hline$R^{2}$ & \multicolumn{2}{|c|}{0,853437} \\
\hline$F(10,981)$ & \multicolumn{2}{|c|}{53,62543} \\
\hline Statystyka testu Breuscha-Pagana & \multicolumn{2}{|c|}{0,355208} \\
\hline Statystyka testu Hausmana & \multicolumn{2}{|c|}{130,46} \\
\hline
\end{tabular}

Źródło: badania własne.

Co ciekawe, na podstawie oszacowanego modelu ceteris paribus można było stwierdzić, że przyrost funduszy własnych banku o $1 \mathrm{mln}$ zł wiązał się ze wzrostem marży finansowej o 0,16 punktu procentowego. Przyrost kredytów 
dla przedsiębiorstw i spółek prywatnych oraz spółdzielni, kredytów dla osób prywatnych oraz kredytów sektora rolniczego również powodował zwiększanie się marży finansowej banków spółdzielczych. W przypadku takich zmiennych jak liczba zatrudnionych i współczynnik wypłacalności stwierdzono ujemny współczynnik regresji, co oznacza, że ich wzrost przyczyniał się do zmniejszania się marży finansowej, ponieważ wzrost współczynnika wypłacalności przyczyniał się do niewykorzystania posiadanej bazy kapitałowej. Z drugiej strony zwiększanie zatrudnienia także nie przynosiło wystarczających korzyści.

W przypadku pozostałych zmiennych dotyczących depozytów i środków na rachunkach bieżących klientów banku stwierdzono ujemny wpływ na poziom marży finansowej banków spółdzielczych.

Tabela 5. Zestawienie zmiennych określających poszczególne rodzaje efektywności banków spółdzielczych w okresie badawczym

\begin{tabular}{|l|c|c|c|c|}
\hline \multicolumn{1}{|c|}{ Zmienna } & Zysk netto & $R O E$ & $R O A$ & $\begin{array}{c}\text { Marża } \\
\text { finansowa }\end{array}$ \\
\hline$X_{2}-$ fundusze własne banku (tys. zł) & tak & - & tak & tak \\
\hline$X_{3}-$ liczba zatrudnionych (osoby) & tak & tak & tak & tak \\
\hline$X_{4}-$ współczynnik wypłacalności (\%) & - & tak & tak & tak \\
\hline $\begin{array}{l}X_{6}-\text { kredyty dla przedsiębiorstw i spółek } \\
\text { prywatnych oraz spółdzielni (tys. zł) }\end{array}$ & tak & - & - & tak \\
\hline $\begin{array}{l}X_{7}-\text { kredyty dla przedsiębiorców indywidu- } \\
\text { alnych (tys. zł) }\end{array}$ & tak & - & - & - \\
\hline$X_{8}-$ kredyty dla osób prywatnych (tys. zł) & - & - & tak & tak \\
\hline$X_{9}-$ kredyty sektora rolniczego (tys. zł) & tak & tak & tak & tak \\
\hline $\begin{array}{l}X_{10}-\text { kredyty dla instytucji niekomercyjnych } \\
\text { (tys. zł) }\end{array}$ & tak & tak & - & - \\
\hline $\begin{array}{l}X_{12}-\text { depozyty przedsiębiorstw i spółek } \\
\text { prywatnych oraz spółdzielni (tys. zł) }\end{array}$ & tak & tak & tak & tak \\
\hline $\begin{array}{l}X_{13}-\text { depozyty przedsiębiorców indywidual- } \\
\text { nych (tys. zł) }\end{array}$ & tak & tak & tak & tak \\
\hline$X_{14}-$ depozyty osób prywatnych (tys. zł) & tak & - & tak & tak \\
\hline $\begin{array}{l}X_{17}-\text { środki zgromadzone na rachunkach } \\
\text { bieżących przez klientów banku (tys. zł) }\end{array}$ & tak & - & tak & tak \\
\hline
\end{tabular}

Źródło: badania własne.

W tabeli 5 przedstawiono podsumowanie dotyczące czynników wpływających na poszczególne miary efektywności przyjęte w badaniach. W oszacowanych modelach wykorzystano łącznie 12 zmiennych, przy czym najwięcej zmiennych było istotnych w przypadku określania poziomu zysku netto. Najmniej zmiennych 
natomiast, biorąc pod uwagę oszacowane modele panelowe, oddziaływało na poziom rentowności funduszy własnych banków spółdzielczych. W przypadku zmienności $R O A$ ustalono 9, a w odniesieniu do marży finansowej 10 zmiennych. Ważne jest to, że niezależnie do przyjętej miary efektywności we wszystkich oszacowanych modelach znalazły się 4 zmienne, $\mathrm{tj}$.:

- liczba zatrudnionych,

- kredyty dla sektora rolniczego,

- depozyty przedsiębiorstw i spółek prywatnych oraz spółdzielni,

- depozyty od przedsiębiorców indywidualnych.

Co ciekawe i ważne, liczba zatrudnionych i poziom depozytów od przedsiębiorstw i spółek prywatnych we wszystkich modelach charakteryzowały się ujemnym współczynnikiem regresji. Wskazuje to na konieczność zwrócenia na nie uwagi, ponieważ przyczyniają się one do zmniejszania efektywności banków spółdzielczych. Istotne jest również to, że 4 zmienne, tj.: fundusze własne banku, współczynnik wypłacalności, depozyty osób prywatnych oraz środki zgromadzone na rachunkach bieżących przez klientów, znalazły się w trzech na cztery oszacowane modele, co wskazuje na ich duże znaczenie dla badanych banków spółdzielczych.

\section{Podsumowanie}

Przeprowadzone badania wykazały, że kluczowymi czynnikami wpływającymi na poziom generowanego zysku netto przez badane banki spółdzielcze były: fundusze własne, liczba zatrudnionych, współczynnik wypłacalności, kredyty dla przedsiębiorstw, spółek prywatnych i spółdzielni, kredyty dla przedsiębiorców indywidualnych, kredyty dla sektora rolniczego, kredyty dla instytucji niekomercyjnych, depozyty przedsiębiorstw, spółek prywatnych i spółdzielni, depozyty przedsiębiorstw indywidualnych, depozyty osób prywatnych oraz środki zgromadzone na rachunkach bieżących przez klientów banków. Świadczy to o tym, że banki spółdzielcze w porównaniu z bankami komercyjnymi prowadzą mniej ryzykowną działalność - ograniczają się na ogół do tradycyjnych usług bankowych.

W przypadku badanych banków spółdzielczych stwierdzono, że na rentowność ich funduszy własnych kluczowy wpływ miały następujące zmienne: liczba zatrudnionych, współczynnik wypłacalności, kredyty sektora rolniczego, kredyty instytucji niekomercyjnych, depozyty przedsiębiorstw, spółek prywatnych i spółdzielni oraz depozyty przedsiębiorców indywidualnych. Ponadto stwierdzono, że z sześciu zmiennych kluczowych dla $R O E$ tylko kredyty sektora rolniczego i kredyty dla instytucji niekomercyjnych charakteryzowały się dodatnim wpływem. Może to oznaczać, że zmienne te są ważne dla badanych banków, jeśli 
chodzi o zarządzanie ich funduszami, a w konsekwencji efektywnością banków spółdzielczych.

Na podstawie badań stwierdzono również, że spośród zmiennych wpływających na poziom rentowności aktywów ogółem oraz marży finansowej kluczowe były następujące zmienne: fundusze własne banku, liczba zatrudnionych, współczynnik wypłacalności, kredyty dla osób prywatnych, kredyty sektora rolniczego, depozyty przedsiębiorstw i spółek prywatnych, depozyty przedsiębiorstw indywidualnych oraz środki zgromadzone na rachunkach bieżących klientów banków. Może to oznaczać, że w przypadku dążenia do uzyskiwania jak największej efektywności w tym zakresie banki spółdzielcze powinny zwracać uwagę na te zmienne, gdyż są one silnie związane z ROE i marżą finansową.

Badania wykazały ponadto, że niezależnie do tego, jaką miarą efektywności kieruje się bank przy podejmowaniu decyzji, ważne jest, aby zwracać szczególną uwagę na poziom funduszy własnych, liczbę zatrudnionych, współczynnik wypłacalności, kredyty dla sektora rolniczego, depozyty od przedsiębiorstw i spółek prywatnych, depozyty osób prywatnych oraz środki zgromadzone na rachunkach bieżących klientów, gdyż te zmienne występowały w co najmniej trzech na cztery oszacowane modele charakteryzujące efektywność badanych banków. Zarządzanie nimi jest szczególne ważne, ponieważ od tego, jak będą się one kształtować, zależy efektywność banku, a w konsekwencji jego kondycja finansowa.

\section{Literatura}

Balina R., Kowalski O., Różyński J. [2014], Effective Management of Own Funds in Polish Cooperative Banks, „Chinese Business Review” 2014, vol. 13, nr 3.

Balina R., Pochopień J., Idasz-Balina M. [2013], Zadania banków zrzeszajqcych i ich znaczenie w opinii zarzqdzajqcych bankami spółdzielczymi, Zeszyty Naukowe Wyższej Szkoły Humanitas: Zarząadzanie, nr 2.

Borkowski B., Dudek H., Szczęsny W. [2003], Ekonometria. Wybrane zagadnienia, Wydawnictwo Naukowe PWN, Warszawa.

Draper N.R., Smith H. [1998], Applied Regression Analysis, John Wiley and Sons, New York.

Dziechciarz J. [2003], Ekonometria. Metody, przykłady, zadania, Wydawnictwo Akademii Ekonomicznej we Wrocławiu, Wrocław.

Farrel M.J. [2008], The Measurement of Productive Efficiency, ,Journal of the Royal Statistical Society", nr 120.

Jaworski W.L. [1997], Bankowość - podstawowe założenia, Poltext, Warszawa.

Juszczyk S., Balina R., Stola E., Różyński J. [2014], Fundusze udziałowe kluczowym narzędziem rozwoju bankowości spótdzielczej w Polsce, Zeszyty Naukowe Uniwersytetu Szczecińskiego: Finanse. Rynki Finansowe. Ubezpieczenia, nr 802(65).

Maddala G.S. [2006], Ekonometria, Wydawnictwo Naukowe PWN, Warszawa.

Mikołajczak R. [1998], Bankowy sektor spółdzielczy wczoraj i dziś, Rocznik Prawniczy, Ekonomiczny i Socjologiczny, nr 3-4. 
Pindyck R.S., Rubinfeld D.L. [1998], Econometric Models and Economic Forecasts, McGraw-Hill, Boston.

Stiroh K. [2004], Diversification in Banking: Is Noninterest Income the Answer?, „,ournal of Money, Credit and Banking", nr 36.

Szambelańczyk J. [2006], Banki spółdzielcze w Polsce w procesach zmian systemowych, Wydawnictwo Akademii Ekonomicznej w Poznaniu, Poznań

Ušàk M. [2006], Grupowanie, zrzeszanie i łqczenie się banków [w:] Prawo bankowe $w$ zarysie, red. E. Fojcik-Mastalska, Wydawnictwo Uniwersytetu Wrocławskiego, Wrocław.

\section{Efficiency Determinants of Cooperative Banks in Poland in 2005-2012}

The study attempts to identify the key factors affecting the efficiency of Polish cooperative banks in 2005-2012. The study included 124 randomly selected cooperative banks in operation in the period studied. Factors determining the level of net profit, return on equity, return on total assets and financial margin were examined at the banks surveyed. Twenty variables that could determine the economic and financial situation of cooperative banks were first considered. Of these, twelve turned out to be relevant. It is important that the three key variables were independent of the adopted measures of efficiency, that is, loans to the agricultural sector, the deposits of enterprises, private companies and cooperatives, and the deposits of individual entrepreneurs.

Keywords: efficiency, models, cooperative banks, return on equity. 